\title{
Expert Information as an Evidence of Criminal Act of Corruption in Goods and Services Procurement
}

\author{
I Gusti Ayu Stefani Ratna Maharani ${ }^{1}$ \\ ${ }^{1}$ Master of Law Program, Faculty of Law, Udayana University \\ E-mail: stefanimaharani70@gmail.com
}

\begin{tabular}{l}
\hline Info Artikel \\
Received: $3^{\text {rd }}$ April 2018 \\
Accepted: $29^{\text {th }}$ September 2018 \\
Published: $30^{\text {th }}$ September 2018 \\
Keywords: $\quad$ Criminal Act of Corruption in \\
Government's Goods and \\
Services Procurement; Criminal \\
Code Procedures; Expert \\
Information \\
Corresponding Author: \\
I Gusti Ayu Stefani Ratna \\
Maharani, E-mail: \\
stefanimaharani70@gmail.com \\
DOI: \\
10.24843/JMHU.2018.v07.i03.p \\
01
\end{tabular}

\begin{abstract}
This research is focused to identify and analyze the role of the expert information as evidence in the case of corruption. One of the criminal acts of corruption that often occurs in the government is the criminal act of corruption in goods and services procurement, in which the perpetrators have abused the social aid fund from the government. There was the case of criminal act of corruption in goods and services procurement for social aid fund that occurred in Tabanan-Bali, which committed by I Wayan Sukaja, who had corrupted the State's financial or social aid fund. Within the process of verification in the trial, the public prosecutors submit 2 (two) experts who provided information to assist in terms of verification. This study uses normative research methods. The purpose of this study is to analyze the role of expert information as evidence in criminal act of corruption. The role of an expert cannot be ignored because it will help the judges, prosecutors and lawyers who have limited knowledge. If the expert's information is contrary, it could be ruled out by the judges but the expert's information that excluded must be based on clear reason, and the judges must have strong base in assess the role of the expert's information.
\end{abstract}

\section{Introduction}

Corruption is an example of the white collar crimes. Unlike any other conventional crimes which would involve violence (street crime, blue collar crime, blue jeans crime), the perpetrators of this white collar crime usually are those elites with high social status and highly educated. Its modus operandi is more likely to be done in a sophisticated way, and sometimes even include scientific theories of certain knowledge such as accounting and statistics ${ }^{1}$.

${ }^{1}$ Arsyad, J. H. (2013). Korupsi dalam Perspektif HAN (Hukum Administrasi Negara). Sinar Grafika, p. 2. 
Criminal act of corruption is one of some special crimes which regulated outside The Criminal Code 2 . Corruption in a comprehensive context is a white collar crime which its modus operandi continues to grow in every aspect. White collar crime is also said to be "an invisible crime", and often requires a system approach to eradicate it since it is quite hard to acquire its procedural verification. Generally, white collar crimes are not easily traceable 3 . Corruption is not only about criminalization, but also how the policy of criminal law facing the invisible crime4. Law No. 31 of 1999 juncto Law No. 20 of 2001 about Eradication of The Criminal Act of Corruption is actually emphasizing on both criminalization for the perpetrators of corruption and State's financial loss due to the corruption. In the perspective of Law No. 31 of 1999 juncto Law No. 20 of 2001, State's loss is something which is caused by an act against the law or abuse of power, authority, and opportunity related to his post or position ${ }^{5}$. Law of Eradication of The Criminal Act of Corruption was born in the atmosphere of Indonesian people who demand clean and good governance and also has a public accountability ${ }^{6}$. The cause of corruption is the lack of moral integrity which is also weakens the national discipline. In addition, the weak systems and mechanisms in various sectors of bureaucracy and law enforcement are also become one of the causes ${ }^{7}$.

Some forms of corruption that often occur in Indonesia including embezzlement, budget mark ups, budget misuse, and misuse of social aid fund for the poor. Criminal Act of Corruption in Goods and Services Procurement is one of the frequent types among it, which has abused social aid funds from State and or Regional's budgets. One of the cases that happened in Bali was the case from Tabanan which committed by I Wayan Sukaja as The Head of Regional House of Representatives for 2004-2009. There were irregularities carried out in this case which resulted in corruption of State's financial budget.

Verification holds an essential role in the investigation process at the trial. Through the verification the fate of defendant is determined. Verification as an activity is an attempt to prove something (an object that is proven), through evidence that may be used in certain ways to state whether what has been shown is proven by law or not. The

${ }^{2}$ Dewi, K. K. S. (2014). Efektifitas Penerapan Ancaman Sanksi Pidana Tambahan Guna Pengembalian Kerugian Keuangan Negara dalam Tindak Pidana Korupsi (Studi Kasus di Pengadilan Negeri Denpasar). Jurnal Magister Hukum Udayana (Udayana Master Law Journal), 3(3). 357-369. https:// doi.org/10.24843/JMHU.2014.v03.i03.p01.

${ }^{3}$ Natasasmita, B. I. (2011). Diskresi sebagai Tindak Pidana Korupsi: Kajian Kriminologi dan Hukum terhadap Fenomena Pejabat Otoritas. MIMBAR, Jurnal Sosial dan Pembangunan, 27(2), 143-149

${ }^{4}$ Adji, I. S. (2009). Korupsi dan penegakan hukum.Jakarta: Diadit Media, p.191.

${ }^{5}$ Arsyad, J. H. op.,cit, p. 174.

${ }^{6}$ Lubis, F. H., \& Marlina, M. (2010). Penegakan Hukum dalam Tindak Pidana Korupsi Pengadaan Barang dan Jasa (Studi pada Pengadilan Negeri Kuala Simpang). Jurnal Mercatoria, 3(2), 88-101.

7 Pasaribu, Laurance Hasiholan, Kajian Yuridis Terhadap Putusan Bebas Tindak Pidana Korupsi (Studi Kasus Pada Pengadilan Medan), Jurnal Magister Hukum UMA Vol. 1 No. 2. 130-14. 
principle of minimum verification is a principle that regulates the limits that should be fulfilled to prove the defendant's fault. In article 184, paragraph 1 of Criminal Code Procedures states that one of the legal evidence types which may be used to prove evidence is an expert's information.

The presence of an expert in providing information on an investigation into the occurrence of Criminal Law (in this case, the criminal act of corruption) becomes very important in all stages of investigation, both in the stage of investigation, action, even report delivery to public prosecutor ${ }^{8}$. The role of experts is needed because it will help the judges, prosecutors and lawyers who have limited knowledge. The expert information is also necessary to convince the judge if the presented evidence is less optimal. In the case of Criminal Act of Corruption which committed by I Wayan Sukaja, in the matter of verification at the trial the public prosecutor presented 2 (two) experts to provide information in order to assist in the verification process 9 .

Based on the description of the background mentioned above, it is clear that there is a large influence of evidence in terms of verification of proving the Criminal Act of Corruption in Goods and Services Procurement in the trial, especially at Denpasar Criminal Act of Corruption Court. Based on this background, the author is interested to conduct a research with the title "Expert Information as An Evidence of Criminal Act of Corruption in Goods and Services Procurement". The focuses of the study to be discussed are as follows: First, why is the expert information necessary in the verification process of proving case of Criminal Act of Corruption? Second, what is the role of expert information as evidence in terms of proving case of Criminal Act of Corruption in Goods and Services Procurement, regarding the decision of the Corruption Court No: 01 / PID.SUS / 2013 / P.TIPIKOR DPS ?

In this study, the researcher displays originality from several studies that have correlation with the researcher's but with different substances. The mentioned researches are as follows:

First, Journal of A.A. Mirah Endraswari, from Master of Law Udayana Vol. 5 No.2 p. 392-405 which titled Application of Shifting Burden of Proof in the Deprivation of Illicit Enrichment Related to Human Rights ${ }^{10}$. This journal discussed about shifting burden of proof arrangement which regulated in Indonesia Criminal Law system, and its application of deprivation of illicit enrichment related to human rights.

Second, Journal of I Putu Gede Sumariartha Suara, in Master of Law of Udayana Vol 6 No. 3 p. 369-382 which titled Reform of the Authority of the Public Prosecutor against

${ }^{8}$ Andi, S., \& Asis, A. (2014). Hukum Acara Pidana Suatu Pengantar. Jakarta: Prenadamedia Group, p. 246.

9 Source: Decision No: 01/PID.SUS/2013/P.TIPIKOR DPS at Denpasar Criminal Act of Corruption Court .

${ }^{10}$ Endraswari, A. M. (2016). Penerapan Beban Pembuktian Terbalik Dalam Perampasan Illicit Enrichment Kaitannya Dengan Hak Asasi Manusia. Jurnal Magister Hukum Udayana (Udayana Master Law Journal), 5(2), 392-405. https://doi.org/10.24843/JMHU.2016.v05.i02.p13 
the Application of Crown Witnesses in the Trial of a Criminal Act of Corruption ${ }^{11}$. This journal discussed the regulation of public prosecutor authority on the application of crown witnesses in proving corruption, according to the Indonesian positive law perspective (ius constitutum) and the formulation of authority for the public prosecutor on the application of crown witnesses in proving corruption according to the upcoming legal perspective (ius constituendum).

Third, Journal of Juangga Saputra Dalimunthe in the Master of Law Journal, North Sumatra University Vol.4 No.1 p. 127-138 which titled Electronic Documents as Evidence in Perspective of Reforming Indonesian Civil Procedure Law ${ }^{12}$.

Of the three studies that have been done previously, the study which researcher specifically examine is the role of expert information as evidence in Criminal Act of Corruption in Goods and Services Procurement.

This legal research writing has 2 (two) objectives namely general purpose and special purpose. The general purpose of this research is to understand the importance of the role of evidence from expert information in Criminal Act of Corruption in Goods and Services Procurement. The specific objective of this study is to describe and analyze why expert information is needed in the process of proving the case of Criminal Act of Corruption, and to describe and analyze the role of expert information as evidence in the case of Criminal Act of Corruption in Goods and Services Procurement.

\section{Research Method}

The research method used in this study is normative legal research, in which according to Soerjono Soekanto, normative legal research is a legal research conducted by examining library materials which means that this study is done by examining norms, principles, philosophy and or doctrine and legal principles in materials literature ${ }^{13}$.

The type of approach used in this research is The Case Approach which is carried out by looking at cases of corruption which in this case examines the role of expert information as evidence in the verification process at the Denpasar Criminal Act of Corruption Court.

The sources of material in this normative research consist of two legal materials: primary legal material and secondary legal material. Primary legal material is legal

11 Suara, I. P. G. S. (2017). Reformulasi Kewenangan Penuntut Umum Terhadap Penerapan Saksi Mahkota Dalam Pembuktian Tindak Pidana Korupsi. Jurnal Magister Hukum Udayana (Udayana Master Law Journal), 6(3), 369-382. https:// doi.org/10.24843/JMHU.2017.v06.i03.p08

12 Tarigan, M. I., Runtung, R., Ginting, B., \& Harianto, D. (2015). Dokumen Elektronik Sebagai Alat Bukti Dalam Perspektif Pembaruan Hukum Acara Perdata Indonesia. USU Law Journal, $4(1), 127-138$.

${ }^{13}$ Sukanto, S., \& Mamudji, S. (2009). Penelitian Hukum Normatif Suatu Tinjauan Singkat, Cet. 11. Jakarta: PT. Raja Grafindo Persada, p. 14. 
material obtained from the constitutional laws and regulations that apply ${ }^{14}$, especially related to criminal act of corruption and evidence in criminal procedure law. Secondary legal materials are legal materials which have many correlations with primary legal materials and function to assist, analyze and understand primary legal materials consisting of legal books, journals or scientific works related to evidence of expert information in criminal act of corruption in goods and services procurement.

Legal material collection techniques used in this study is using a card system, which is compiled based on the subject matter in the study. Materials recorded on the card include problems, arguments, steps taken, consequences and alternative problem solving.

\section{Result and Discussion}

\subsection{Expert Information is Required in the Verification Process of Criminal Act of Corruption}

Verification as an activity is an attempt to prove something (an object that is proven), through evidence that may be used in certain ways to state whether what has been shown could be proven according to law or not. The process of proving the activities carried out jointly by three parties, namely prosecutors, judges and defendants accompanied by lawyers, which all aspects have been determined and regulated by law. ${ }^{15}$

Expert information is information given by someone who has special expertise about the things needed to make the light of a case for the purposes of the examination (Article 1 number 28 of the Criminal Procedure Code). What content must be explained by the expert, and what conditions must be fulfilled so that the expert's information has a value not stipulated in the Criminal Procedure Code, but it can be thought that based on Article 1 number 28 of the Criminal Procedure Code, specifically there are 2 (two) requirements of the expert information:

a) What is explained must be about everything that falls within the scope of his expertise.

b) What is explained about his expertise was closely related to the case being examined. ${ }^{16}$

The period of HIR (Herziene Indonesian Reglement) expert information is not categorized as evidence of criminal proceedings. HIR does not view expert information as a valid proof, but considers it as a statement that can be used as a judge to be his own opinion, if the judge considers that the expert's information can be accepted. Article 184 paragraph (1) of the Criminal Code Procedure has stated expert information

14 Marzuki, P. M. (2017). Penelitian Hukum, Jakarta: Kencana Predana Media Group, p. 93.

${ }^{15}$ Isnaini, I. (2017). Kajian Hukum Terhadap Keterangan Ahli (Dokter) Dalam Pembuktian Kasus Penyalahgunaan Narkotika. Jurnal Mercatoria, 7(2), 125-143.

${ }^{16}$ Kusmayadi, S. A. Penegakan Hukum terhadap Dokter yang Menolak Pembuatan Visum Et Repertum dalam Tindak Pidana Pembunuhan (Studi Kalimatan Barat). Jurnal Nestor Magister Hukum, 3(5). 1-30. 
as a legal evidence and is located in the second place after evidence of witness testimony. The value of verification strength of an expert is as the same as of the evidence of witness information. Therefore the value of verification that is attached to the evidence of expert information, namely having the value of a free verification force (vrij bewijskracht) means that there is no requirement for the judge to accept the truth of the expert information, but the judge must be truly responsible and in accordance with the minimum evidentiary principle regulated in Article 183 of the Criminal Code Procedure, an independent expert's information without being supported by one of other evidences, is not sufficient to prove the defendant's guilt.

The evidence used in proving Criminal Act of Corruption is the same with the one used in other general crimes as stated in Article 184 of the Criminal Code Procedure. To prove the occurrence of corruption, the role and position of evidence that is formed through the means of proof of information and documentary evidence must be added with at least one legal evidence, for example, supplemented with evidence of expert's information. The need of an expert in a trial of criminal case is a logic consequence of law development in the society. Bismar Siregar assesses that improving people's lives also means increasing legal needs. ${ }^{17}$

The existence of expert information in Criminal Code Procedure means that the role of an expert in a case investigation, both in scrutiny and trial level cannot be ignored. Expert information is very useful in the process of proving cases of corruption. Expert information is needed because both public prosecutors, lawyers, and judges have limited knowledge. Expert information is also useful to convince judges and defendants and lawyers that accompanies them when the evidence served is less optimal. Djoko Prakoso emphasizes that the Criminal Code Procedure has determined the expert's information as a legal evidence, that can't be ignored by the judge.

The judge cannot ignore the expert's information but if the process of proving a criminal act requires a lot of expertise of experts who master science and technology, then the judge must adjust his assessment of the existence of expert information with the criminal case he handled, and has an argument in accepting or rejecting it. Experts are needed to maintain objectivity in the trial. The expert will be on the truth side according to his skill. The expert is considered as a neutral party so that he can provide clear opinions and not influenced by charge assumption filed by the public prosecutor.

\subsection{The Role of Expert Information as An Evidence in Verification of Criminal Act of Corruption in Goods and Services Procurement in the Court Ruling of Criminal Act of Corruption No: 01 / PID.SUS / 2013 / P.TIPIKOR DPS.}

The case of Criminal Act of Corruption sometimes require expert information to make a case clear, so the public prosecutor, judge, and lawyers will present an expert to provide information in a trial. His information is not any information, but the experts must have skills related to the case in the trial. In the Court Ruling number: 01 / PID.SUS / 2013 / P.TIPIKOR DPS, there are 3 (three) cases of corruption which present expert information in the trial, namely:

17 Barda Nawawi Arief, S. H. (2016). Bunga rampai kebijakan hukum pidana. Prenada Media, p.9. 
Tabel 1

\begin{tabular}{|c|c|}
\hline Court Ruling & $\begin{array}{llll}\text { Criminal } & \text { Act } & \text { of } & \text { Loss } \\
\text { Corruption } & & & \end{array}$ \\
\hline $\begin{array}{l}01 \text { / PID.SUS / } 2013 \text { / } \\
\text { P.TIPIKOR DPS }\end{array}$ & $\begin{array}{l}\text { Budget fund (social aid) to } \mathrm{Rp} .75 .000 .000 \text { (seventy } \\
\text { build water reservoir in five million rupiahs) } \\
\text { Balai Serba Guna Marga } \\
\text { Village and Subak Spring } \\
\text { Bene, Marga sub-district }\end{array}$ \\
\hline \multirow[t]{2}{*}{$\begin{array}{l}\text { Defendant: I } \quad \text { Wayan } \\
\text { Sukaja }\end{array}$} & $\begin{array}{llll}\text { Budget fund (social aid) } & \text { Rp. } 150.000 .000 & \text { (one } \\
\text { for building Useh Temple hundred fifty million } & \text { hed } \\
\text { and village temple in rupiahs) } & & \\
\text { Banjar Munduk Pakel, } & & \\
\text { Gadung Sari Village, East } & & \\
\text { Selemadeg sub-district } & & & \\
\end{array}$ \\
\hline & $\begin{array}{lllr}\text { Budget fund (social aid) } & \text { Rp. 230.000.000 } & \text { (two } \\
\text { for building temple hundred thirty million } \\
\text { renovation in Pekraman rupiahs) } & & \\
\text { Village of Bunyuhm, } & & \\
\text { Perean Village, Baturiti } & & \\
\text { sub-district } & & & \\
\end{array}$ \\
\hline
\end{tabular}

Source: Court Ruling No. 01 / PID.SUS / 2013 / P.TIPIKOR DPS.

Several Criminal Act of Corruption mentioned above regarding the abuse of social health in Tabanan District. Regarding so much loss by the act, extra effort should be done towards them. In this case, for the verification in the trial the public prosecutor presents 2 (two) experts to give their information, namely:

1. Expert Putu Gede Sumartha Yasa (expert in State Administration)

2. Expert I Gusti Ketut Ariawan, (expert in Criminal Law)

One of the judges considerations in imposing penalty to the defendant I Wayan Sukaja is the information given by the expert presented by the public prosecutor, namely I Gusti Ketut Ariawan, who explained the mechanism for managing the state's finance should work in accordance with the written regulations such as Presidential Decree and State Minister's Ordinance from the beginning of submission, disbursement, use / management (by parties who submit), up to the last stage of accountability, because if it is not in accordance with the procedure it will be considered as an act against the law (nature of the formal law as stipulated by the Republic of Indonesia's Constitutional Court No: 003 / PUU-IV / 2006 dated July 25, 2006). The expert also explained that criminal law procedures aim at finding material truths is not merely formal truths, such as in the domain of civil law procedure, so something that is postulated not only proven by formal evidence, but must be traced materially.

The public prosecutor also presents experts in the field of state administrative law, namely Putu Gede Sumartha Yasa, which explains the state finances including regional 
budget, therefore the allocation, management and accountability must be clear and complete, that is why the party who submit must also be the party that manages. This is what is meant by responsibility concept of State financial. In addition, the expert also explained that State financial assistance (public scope), not private money because it is obtained from the regional budget in which the allocation is clear according to the shopping budget plan (RAB) proposal, not obtained in a transactional manner that is private. In connection with the Court Ruling Number: 01 / PID.SUS / 2013 / P.TIPIKOR DPS on May 2, 2013 on behalf of the defendant I Wayan Sukaja, stating that the defendant is legally and convincingly proven guilty of committing corruption together. According to the judge's consideration of the elements in the primary indictment, namely Article 2 paragraph (1) juncto Article 18 paragraph (1) letter (b) of Law Number 31 of 1999 juncto Act Number 20 of 2001, concerning Amendments to the Law Number 31 of 1999 concerning Eradication of Criminal Act of Corruption in Article 55 paragraph (1) of the $1^{\text {st }}$ Criminal Code in conjunction with Article 65 paragraph (1) of the Criminal Code.

\section{Conclusion}

Information from experts according to the Criminal Code Procedure in proving criminal cases is one of the five evidences contained in Article 184 of the Criminal Code Procedure. Article 184 paragraph (1) of the Criminal Code Procedure stated that expert's information is a valid evidence. The role of expert's information as an evidence in proving Criminal Act of Corruption crime in goods and services procurement of government in Court Ruling number: 01 / PID.SUS / 2013 / P.TIPIKOR DPS on May 2, 2013 on behalf of Defendant I Wayan Sukaja has been legally proven and convincing guilty of committing a criminal act of corruption jointly by doing an act which is considered as an independent act and is a crime.

One of the judge's considerations in imposing a penalty to the defendant is the information given by the experts presented by the public prosecutor, namely I Gusti Ketut Ariawan, who explained that the mechanism for managing state finances must go according to the flow as stipulated in written regulations such as the Presidential Decree and State Minister's Ordinance. In addition, experts also explained that criminal procedural law aims to find material truths not merely formal truths, so something that is postulated not only proven by formal evidence but must be traced materially.

\section{References}

\section{$\underline{\text { Books }}$}

Adji, I. S. (2009). Korupsi dan penegakan hukum. Jakarta: Diadit Media.

Barda Nawawi Arief, S. H. (2016). Bunga rampai kebijakan hukum pidana. Prenada Media.

Arsyad, J. H. (2013). Korupsi dalam Perspektif HAN (Hukum Administrasi Negara). Sinar Grafika. 
Sukanto, S., \& Mamudji, S. (2009). Penelitian Hukum Normatif Suatu Tinjauan Singkat, Cet. 11. Jakarta: PT. Raja Grafindo Persada.

Andi, S., \& Asis, A. (2014). Hukum Acara Pidana Suatu Pengantar. Jakarta: Prenadamedia Group.

Marzuki, P. M. (2017). Penelitian Hukum, Jakarta: Kencana Predana Media Group.

\section{Article Journal}

Endraswari, A. M. (2016). Penerapan Beban Pembuktian Terbalik Dalam Perampasan Illicit Enrichment Kaitannya Dengan Hak Asasi Manusia. Jurnal Magister Hukum Udayana (Udayana Master Law Journal), 5(2), 392-405. https://doi.org/10.24843/JMHU.2016.v05.i02.p13

Dewi, K. K. S. (2014). Efektifitas Penerapan Ancaman Sanksi Pidana Tambahan Guna Pengembalian Kerugian Keuangan Negara dalam Tindak Pidana Korupsi (Studi Kasus di Pengadilan Negeri Denpasar). Jurnal Magister Hukum Udayana (Udayana $\begin{array}{llll}\text { Master Law 357 3). } & \text { 36urnal), }\end{array}$ https://doi.org/10.24843/JMHU.2014.v03.i03.p01

Natasasmita, B. I. (2011). Diskresi sebagai Tindak Pidana Korupsi: Kajian Kriminologi dan Hukum terhadap Fenomena Pejabat Otoritas. MIMBAR, Jurnal Sosial dan Pembangunan, 27(2), 143-149.

Kusmayadi, S. A. Penegakan Hukum terhadap Dokter yang Menolak Pembuatan Visum Et Repertum dalam Tindak Pidana Pembunuhan (Studi Kalimatan Barat). Jurnal Nestor Magister Hukum, 3(5). 1-30.

Isnaini, I. (2017). Kajian Hukum Terhadap Keterangan Ahli (Dokter) Dalam Pembuktian Kasus Penyalahgunaan Narkotika. Jurnal Mercatoria, 7(2), 125-143.

Lubis, F. H., \& Marlina, M. (2010). Penegakan Hukum dalam Tindak Pidana Korupsi Pengadaan Barang dan Jasa (Studi pada Pengadilan Negeri Kuala Simpang). Jurnal Mercatoria, 3(2), 88-101.

Pasaribu, Laurance Hasiholan, Kajian Yuridis Terhadap Putusan Bebas Tindak Pidana Korupsi (Studi Kasus Pada Pengadilan Medan), Jurnal Magister Hukum UMA Vol. 1 No. 2. 130-14.

Suara, I. P. G. S. (2017). Reformulasi Kewenangan Penuntut Umum Terhadap Penerapan Saksi Mahkota Dalam Pembuktian Tindak Pidana Korupsi. Jurnal Magister Hukum Udayana (Udayana Master Law Journal), 6(3), 369-382. https://doi.org/10.24843/JMHU.2017.v06.i03.p08

Tarigan, M. I., Runtung, R., Ginting, B., \& Harianto, D. (2015). Dokumen Elektronik Sebagai Alat Bukti Dalam Perspektif Pembaruan Hukum Acara Perdata Indonesia. USU Law Journal, 4(1), 127-138. 


\section{$\underline{\text { Laws and Regulations }}$}

Constitution of Republic of Indonesia No. 8 in 1981 of Criminal Code Procedures (Statute Book in 1981 No.76, Additional Statute Book No. 3209).

Constitution of Republic of Indonesia No. 31 in 1999 of Eradication of Criminal Act of Corruption (Statute Book in 1999 No. 140, Additional Statute Book No. 3874).

Constitution of Republic of Indonesia No. 20 in 2001 of The Change of Law No. 31 in 1999 (Statute Book No. 4150). 